\title{
Some fishery aspects of Nile tilapia, Oreochromis niloticus at Rosetta Branch of the Nile River, Egypt
}

\author{
El-Azab E. B. El-Bokhty and A. M. El-Far \\ National Institute of Oceanography and Fisheries, Egypt.
}

\begin{abstract}
Cichlid fish species dominating in Rosetta Branch of the River Nile were studied. They were collected from the commercial catches of widespread used trammel nets during 2008-2009. Analysis of the species composition revealed that Oreochromis niloticus dominated the tilapia catch followed by Oreochromis aureus and Tilapia zillii. The lengthfrequency of the dominated $O$. niloticus varied between 11 and $27 \mathrm{~cm}$ total length and its length weight relationship was $\mathrm{W}=0.023966 \mathrm{~L}^{2.92209}$. The selection range as deduced from the probability of capture varied according to the mesh size used of the inner layer of the net The selection factor corresponding to the compared two different mesh sized nets, that widely used, was also estimated. The results indicated that the mean selection length should be increased to reach at least $15 \mathrm{~cm}$ by increasing the mesh size of the inner layer of trammel nets to $60 \mathrm{~mm}$ stretched mesh or $30 \mathrm{~mm}$ mesh bar. This will lead to increasing the average weight of $O$. niloticus to $65 \mathrm{gm}$. These basic data may be helpful in understanding the mesh selectivity and fishery management of the Nile tilapia.
\end{abstract}

Key words: Oreochromis niloticus, Trammel net, selectivity, River Nile, Egypt.

\section{INTRODUCTION}

Egypt has about $8716 \mathrm{~km}$ of inland waters, including River Nile, lakes, reservoirs and brackish water lagoons. Inland fisheries are generally characterized by smallscale/household-based activities. Participation in fisheries is high and the bulk of the catch is consumed locally. By-catch is insignificant as practically all fish caught are used. Nevertheless, reported catches from inland fisheries are still rising at a linear rate of about 3 per cent per year globally (Welcomme et al., 2010).

The inland fishing fleet comprises over 38500 small wooden boats (4-6 m length) catching about 295500 tonne, or 69 percent of Egyptian landings. Most of the fishermen are unregistered. There are about 270 registered landing sites and many unregistered (GAFRD, 2008).

River Nile fisheries are considered as one of the most important sources of inland fishery in Egypt, and represent about $0.34 \%$ of the total natural fisheries of Egypt during 2009 (GAFRD, 2009). Importance of the fishery returns to two main targets; as a source of animal protein for human consumption and as a source of employment.

For a controlled development and proper management of the River Nile fisheries, basic knowledge on its fish stocks is needed together with adequate biological information on the fish stocks that would assist in evaluating management strategies for a maximum sustainable production. Such research should include a description of the composition and spatial distribution of the fish species, a description of the selective impact of the fishery, an estimation of the dynamic parameters i.e. growth, mortality, reproduction, catch and effort data.

Freshwater fish represent an essential and often irreplaceable source of high quality, allowable and cheap animal protein. Four Cichlid species were identified in the River Nile namely; Oreochromis niloticus, Oreochromis aureus, Sarotherodon galilaeus and Tilapia zillii (Mahmoud and Mazrouh, 2008). 
Due to their importance in the Egyptian inland waters, many studies on their biology and fisheries were done. Abdel Azim (1974), Talaat (1979), Ishak et al. (1985), Bayoumi and Khalil (1988), Akel (1989), Dowidar et al. (1990), Abdel-Baky and ElSerafy (1990), Abdel-Aziz et al. (1990), El-Haweet (1991), El-Shazly (1993), Bakhoum (1994, 1995 \& 2002), Essa and Faltas (1997), Khalifa et al.,(2000), Khallaf et al., (2000), Khallaf (2002), Abd-Alla and Talaat (2000), Adam (2004), Eskander (2004), Abaza (2004), Mehanna (2005), El-Sayed (2006), El-Sayed and Moharram (2007).

Rosetta branch is one of the two main branches of the River Nile (Fig.1). It is about $220 \mathrm{~km}$ in length with an average width of $180 \mathrm{~m}$. and depth varying between 2 and $4 \mathrm{~m}$ (Abd el-Sattar and Elewa 2001). It ends at Idfina Barrage which releases excess water to the Mediterranean Sea. Several studies had been done on Rosetta branch by Massoud and Mahdi (1985 a \& b), Bakry (1996), Abbassy et al. (1999), Abdo (2002), Donia, et al. (2003), AbdAllah, et al. (2006), Mahmoud and Mazrouh (2008), Mazrouh and Mahmoud (2009).

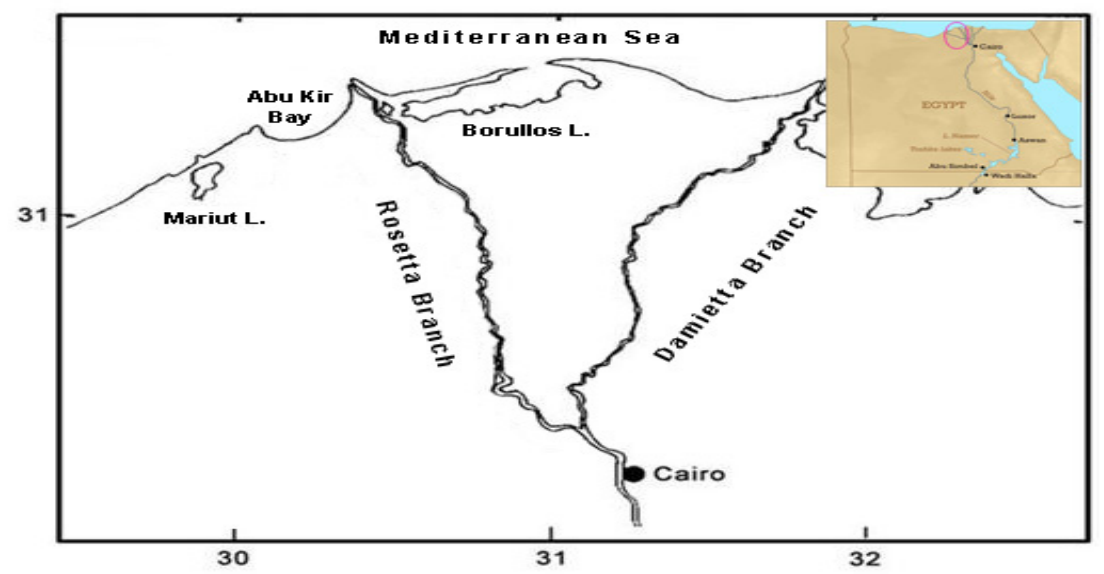

Fig. 1: Location map showing the Nile two branches (C.f. MAHMOUD AND MAZROUH, 2008)

Knowledge of the size-selectivity of fishing gear types is crucial to fisheries management in order to maximize a sustainable yield (Millar and Holst, 1997; Huse et al., 2000; Emmanuel et al., 2008). It is also essential for fish ecology in order to adjust the length distribution of the catches and to understand the population sampled.

Both gillnet and trammel nets have selective impacts on the fish community which may lead to an immediate effect of reducing the proportion of large species and size classes in the stock. Therefore proper management requires an understanding of the effect of mesh size regulation on the fish stocks in the system. Basic information on the fishing gear selectivity is therefore necessary to predict the size of the fish, which will be caught in a net of a particular mesh size.

There is a considerable exploitation pressure on the different species of tilapia fish in Rosetta branch (Mahmoud and Mazrouh, 2008).

O. niloticus which dominated the catch of trammel nets used in Rosetta Branch. Thus information on the fishery status as well as the selectivity of such vital species as affected by the widely used trammel net method is essentially required for sustainable management of its fishery in Rosetta branch.

\section{MATERIALS AND METHODS}

The present study is a part of the scientific project, carried out by NIOF, covering the River Nile from Aswan to Alexandria during 2008-2009 entitled "An integrated scientific discipline for protection of the River Nile from pollutants and increasing fishery resources". 
Sample collections were taken from the fishing boats working at three stations namely; El-Rahawee, Koum Hamada and Kafr El-Zaiat regions during autumn 2008. At the laboratory, fish samples were sorted into species level and for each species; its size frequency was measured by an ordinary measuring board at $1-\mathrm{cm}$ class interval and weighed to the nearest gram for length-weight relationship. The mesh size of the inner layer of trammel nets was measured in mesh bars (i.e. from knot to knot, $\mathrm{cm}$ ) as well as the gear specifications. Length weight relationship was estimated using the power equation $\mathrm{W}=\mathrm{aL}^{\mathrm{b}}$ (Le Cren, 1951) where "a" and "b" are constants.

For the dominated species, the selection range $\left(\mathrm{L}_{25}-\mathrm{L}_{75}\right)$ was calculated as a consecutive step from the length converted catch curve method.

The estimated mean selection length was calculated from the equation:

Mean Selection length $\left(\mathrm{L}_{\mathrm{c}} 50\right)=$ S.F. ${ }^{*}$ Mesh size

Where, S.F. is the selection factor estimated from comparing Ln ratios of the two meshes according to Holt (1957).

\section{RESULTS}

The annual fish catch from River Nile during the period 2002-2009 fluctuated between a maximum catch of 120.9 thousand ton in year 2002 and a minimum catch of 79.7 thousand tons in 2008 with a decreasing trend rate $(-5.1$ thousand tons per year, $\mathrm{R}^{2}=0.66$ ). Tilapia catch fluctuated between 36.3 thousand tons in 2004 and 24.3 thousand tons in 2008 , with a decrasing trend rate $\left(-1.1\right.$ thousand tons per year, $\mathrm{R}^{2}=$ 0.38) (Fig. 2).

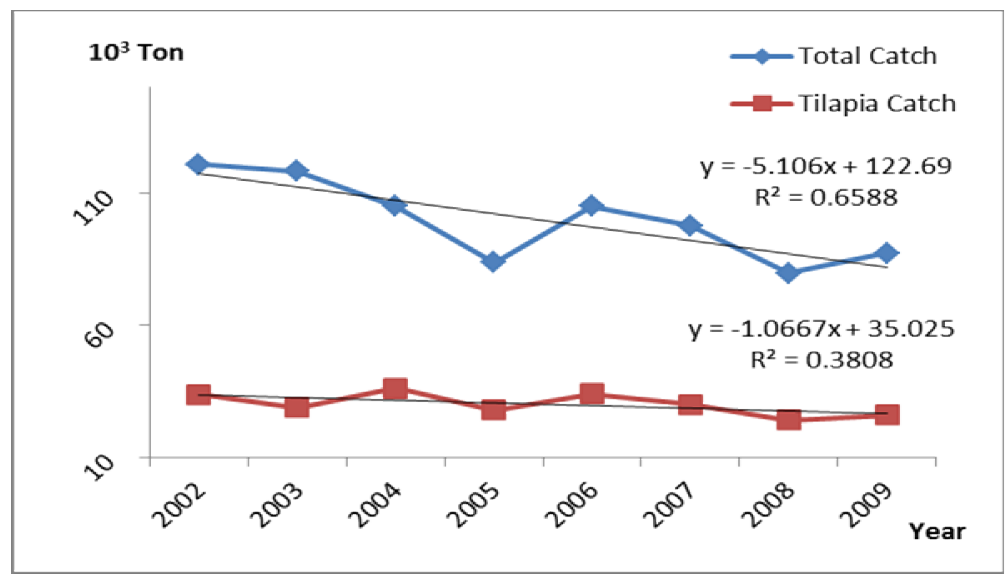

Fig. 2: Total fish and total tilapia catch from River Nile during 2000 - 2009 (GAFRD, 2002-2009).

Small sign of increase of tilapia in 2012 was noticed where it contributed by 31.6 $\%$ and followed by catfish $(20.27 \%)$ and grass carp $(17.91 \%)$ as recorded by GAFRD during 2012.

Fishing by trammel nets in River Nile is usually carried out by small boats of the third class "Canoe-like faloukas without sails" with mean crew size 2 men from the early dawn to near afternoon.

Fishermen employed in fishing use exclusively floating trammel nets (which are commonly used at the River Nile and its tributaries). The trammel nets are constructed by joining three parallel sheets of netting where the two outer sheets are made of netting with large meshes and the inner one with small meshes.

The nets used are with mesh bars ranging from 2.4 to $2.8 \mathrm{~cm}$ for the inner layer and with total lengths varying between 15 and $45 \mathrm{~m}$ for net unit. The net is kept open vertically by the differences in buoyancy between the two ropes. The head rope is supplied with cork floats to provide positive buoyancy, while the foot rope gives a 
negative one under the effect of lead sinkers. These nets are used near the shallow shores to catch almost tilapias. Collection of the catch was taken by small traders on small cars or even motorized bikes to the nearest towns at early morning. Fishermen use simple traditional non motorized (hand-operated) small boats of total lengths from 5 to 8-m made of wood.

\section{Species and size composition}

Species caught by the trammel net fishery were mainly Tilapia species namely Oreochromis niloticus, O. aureus, Sarotherodon galilaeus and Tilapia zillii. As shown in Table (1), O. niloticus dominated the catch (by number and weight) in the three investigated stations. The total length of $O$. niloticus caught at El-Rahawee region varied between 11 and $27 \mathrm{~cm}$ with an average length $14.1 \mathrm{~cm}$. While, the total lengths of $O$. niloticus at Koum Hamada region varied between 12 and $23 \mathrm{~cm}$ with an average 15.3 $\mathrm{cm}$.

Table 1: Species and size compositions of fish caught by trammel nets at Rosetta branch of River Nile.

\begin{tabular}{|c|c|c|c|c|c|c|c|c|c|}
\hline & \multirow{2}{*}{ Area } & Fishing & \multirow{2}{*}{ Sp. } & \multirow{2}{*}{ No. } & \multirow{2}{*}{$\%$} & \multirow{2}{*}{$\begin{array}{l}\text { Wt. } \\
\text { (gm.) }\end{array}$} & \multirow{2}{*}{$\%$} & Length & Av. length \\
\hline & & method & & & & & & range $(\mathrm{cm})$ & \pm S.D.(cm) \\
\hline \multirow{10}{*}{ 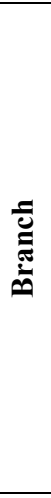 } & \multirow{7}{*}{ 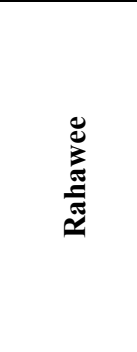 } & \multirow{7}{*}{$\begin{array}{c}\text { Trammel } \\
\text { net }\end{array}$} & O. $n$. & 66 & 63.5 & 6143 & 56.33 & $11.0-27.9$ & $14.09 \pm 4.09$ \\
\hline & & & O. $a$. & 25 & 24.04 & 1096 & 10.05 & $11.0-16.9$ & $13.62 \pm 1.09$ \\
\hline & & & S. $g$. & 4 & 3.85 & 127 & 1.16 & $10.5-12.9$ & \\
\hline & & & T. $z$. & 3 & 2.88 & 119 & 1.09 & $12.1-14.1$ & \\
\hline & & & $\begin{array}{c}\text { Clarias } \\
\text { gariebinus }\end{array}$ & 5 & 4.81 & 3320 & 30.44 & $41.0-48.7$ & \\
\hline & & & Bagrus bajad & 1 & 0.96 & 100 & 0.92 & 24.9 & \\
\hline & & & Total & 104 & & 10905 & & & \\
\hline & \multirow{3}{*}{ Koum } & \multirow{3}{*}{ Trammel } & $O . n$. & 73 & 86.91 & 5255 & 88.8 & $12.0-23.9$ & $15.28 \pm 2.64$ \\
\hline & & & O. $a$. & 1 & 1.19 & 58 & 0.98 & 16 & \\
\hline & & & S. $g$. & 1 & 1.19 & 195 & 3.3 & 20.9 & \\
\hline \multirow{6}{*}{ 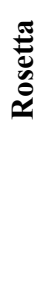 } & \multirow{3}{*}{ Hamada } & \multirow{3}{*}{ net } & T. $z$. & 6 & 7.14 & 295 & 4.98 & $12.8-14.9$ & \\
\hline & & & Other Sp. & 3 & 3.57 & 115 & 1.94 & & \\
\hline & & & Total & 84 & & 5918 & & & \\
\hline & \multirow{3}{*}{$\begin{array}{c}\text { Kafr } \\
\text { El-Zaiat }\end{array}$} & \multirow{3}{*}{$\underset{\text { net }}{\text { Trammel }}$} & $O . n$. & 49 & 77.78 & 2445 & 83.88 & $11.0-21.9$ & $13.52 \pm 1.81$ \\
\hline & & & T. $z$. & 14 & 22.22 & 470 & 16.12 & $10-13.9$ & $12.14 \pm 1.08$ \\
\hline & & & Total & 63 & & 2915 & & & \\
\hline
\end{tabular}

Mesh bars 2.7 and $2.8 \mathrm{~cm}$ for the inner layer of the trammel nets were used at both regions respectively. The average length of $O$. niloticus $(13.5 \mathrm{~cm})$ was reported at Kafr El-Zaiat region which is associated with the decrease of the inner mesh bars of the trammel nets used $(2.45 \mathrm{~cm})$.

A total number of 251 fish were collected from the catch of trammel nets weighing $13843 \mathrm{gm}$ from the investigated 3 stations along Rosetta branch of the River Nile. It was found that $O$. niloticus represented the majority of the catch where it represented $56 \%$, $89 \%$ and $84 \%$ by weight at Rahawee, Koum Hamada and Kafr El-Zaiat regions, respectively.

O. aureus was represented by about $10 \%$ at Rahawee by weight while decreased to reach $0.98 \%$ at Koum Hamada and was not recorded at Kafr El-Zaiat. Its average length was $13.6 \mathrm{~cm}$ at the first station (Table 1 \& Fig. 3). Very little proportions of other species were recorded. 

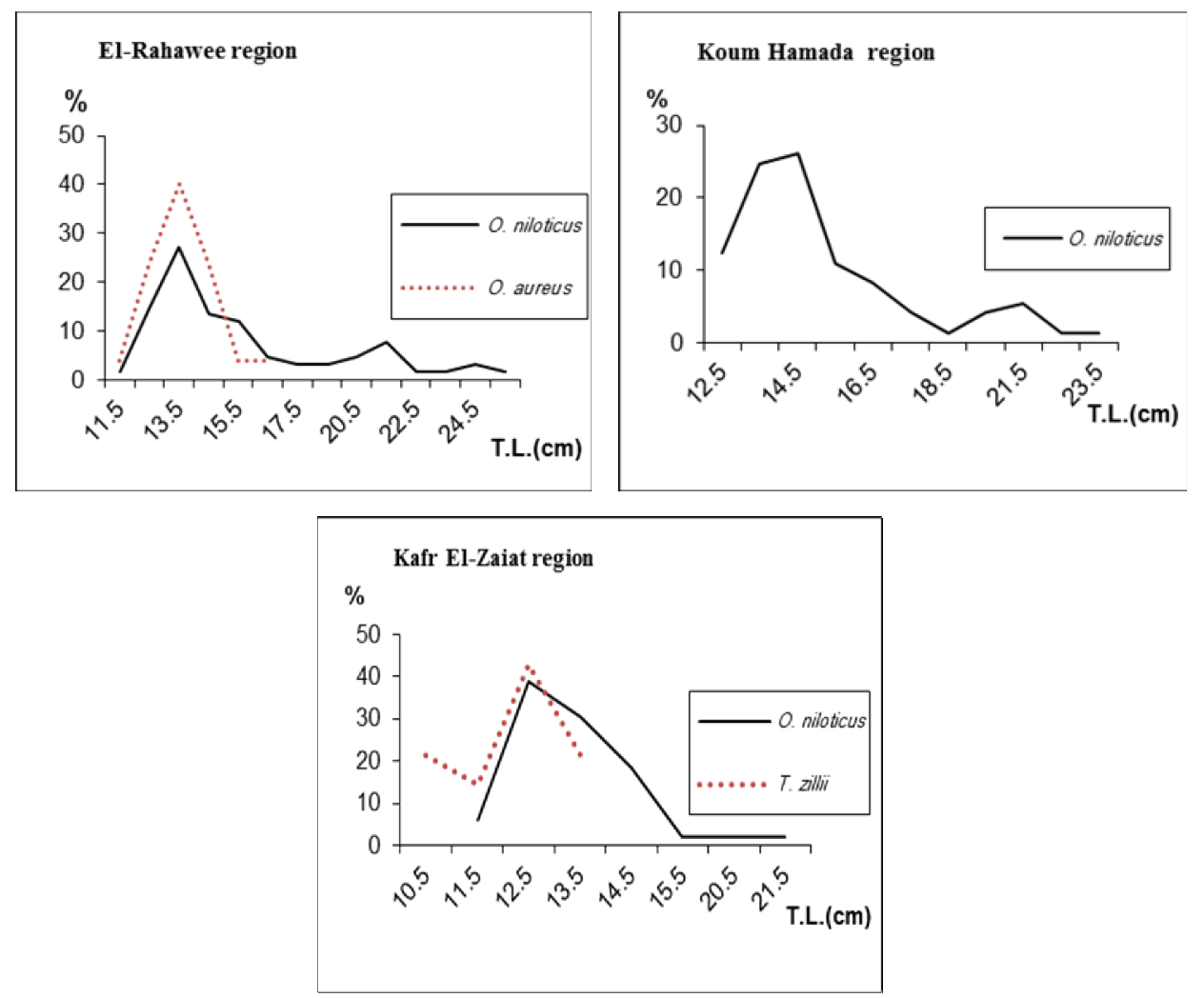

Fig. 3: Length frequency of Tilapia fish caught by trammel net at Rosetta branch, River Nile

\section{Length - Weight relationship}

The total length of $O$. niloticus caught by trammel nets in Rosetta branch varied between 11 and $27 \mathrm{~cm}$ and a total weight ranging between 30 and $360 \mathrm{gm}$. The estimated weight-length relationship for $O$. niloticus can be represented by the following equation;

$\mathrm{W}=0.023966 \mathrm{~L}^{2.92209}(\mathrm{r}=0.9795)$. It was noted that the most frequent group (modal length group) recorded was found at $13.5 \mathrm{~cm}$ at El-Rahawee and $14.5 \mathrm{~cm}$ at Koum Hamada stations which is related to the mesh sizes used in the inner layer of the trammel nets used. On the other hand, the modal length decreased to $12.5 \mathrm{~cm}$ at Kafr El-Zaiat due to the smaller mesh sizes of the inner layer of the trammel nets used compared to those used at the first two stations.

\section{Probability of capture}

The length at first capture $\left(\mathrm{L}_{\mathrm{C}}\right)$ is strongly correlated with the mesh size of the trammel net used. $\mathrm{L}_{\mathrm{c}}$ at which $50 \%$ of the fish that become vulnerable to capture was estimated to be $11.89 \mathrm{~cm}$ for smaller meshed net $(2.4 \mathrm{~cm}$ mesh bar) and $12.22 \mathrm{~cm}$ for the larger one (2.8 $\mathrm{cm}$ mesh bar) (Table 2$)$.

Table 2: Probability of capture $\left(\mathrm{L}_{\mathrm{C}}\right)$ and corresponding calculated weight of $O$. niloticus caught by trammel nets at Rosetta Branch, River Nile.

\begin{tabular}{|c|c|c|}
\hline Item & \multicolumn{2}{|c|}{$\mathbf{L}_{\mathbf{c}}$ values } \\
\hline Mesh bar & $\mathbf{2 . 4} \mathbf{~ c m}$ & $\mathbf{2 . 8} \mathbf{~ c m}$ \\
\hline $\mathbf{L}_{\mathbf{2 5}}(\mathbf{c m})$ & 11.14 & 11.32 \\
Calc. Wt.(gm) & $(27.46)$ & $(28.78)$ \\
\hline $\mathbf{L}_{\mathbf{5 0}}(\mathbf{c m})$ & 11.89 & 12.22 \\
Calc. Wt.(gm) & $(33.22)$ & $(35.98)$ \\
\hline L $_{\mathbf{7 5}}(\mathbf{c m})$ & 12.66 & 12.97 \\
Calc. Wt.(gm) & $(39.9)$ & $(42.83)$ \\
\hline
\end{tabular}


The selection range was found to range between minimum $\left(L_{25}\right) 11.14 \mathrm{~cm}$ and maximum $\left(\mathrm{L}_{75}\right) 12.66 \mathrm{~cm}$ for $O$. niloticus caught by the smaller net. While, it ranged between 11.32 and $12.97 \mathrm{~cm}$ for the larger mesh bar of trammel net (Table $2 \&$ Fig. $4 \mathrm{a}$, b).

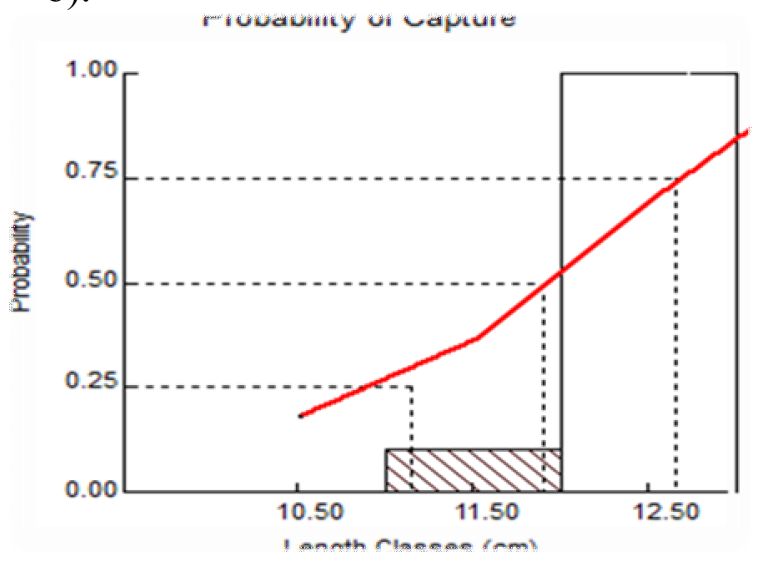

Fig. 4 a: Probability of capture of $O$. niloticus caught by trammel nets $(2.4 \mathrm{~cm}$ mesh bar).

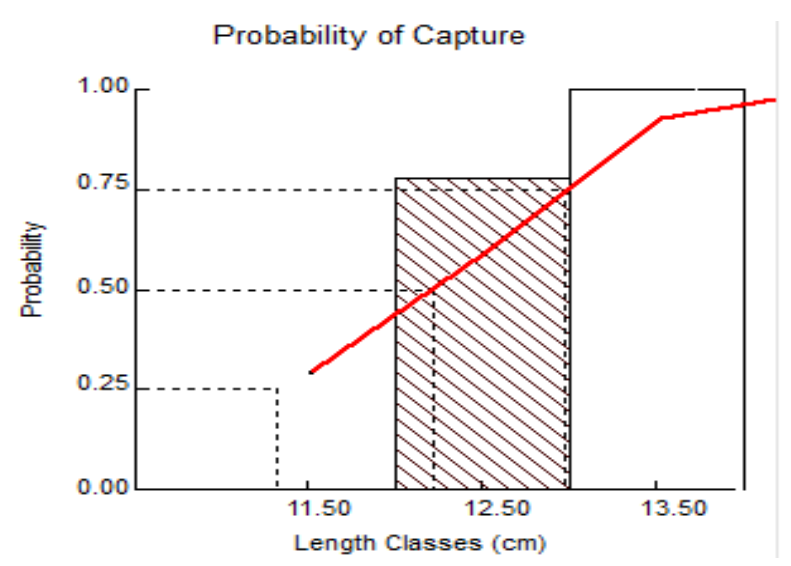

Fig. 4 b: Probability of capture of $O$. niloticus caught by trammel nets $(2.8 \mathrm{~cm}$ mesh bar).

It's noticed also that the calculated weight exceeds slightly 40 gram to the upper range of the larger mesh bar of trammel net (Table 2).

\section{Selection factor}

When comparing the length frequency distribution of the two different meshed trammel nets, there was overlapping between five points between them (Fig. 5). This allows the estimation of the selection factor by comparing Ln ratios according to Holt's method (1957).

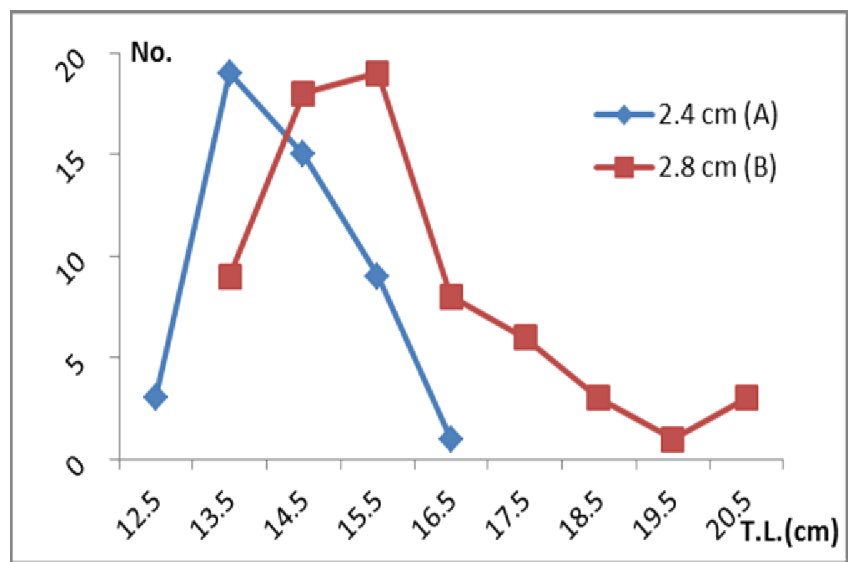

Fig. 5: Length frequency distribution of $O$. niloticus caught by two different trammel nets, Rosetta Branch, River Nile.

It was estimated that the selection factor from the regression eqation was 5.144 (Fig. 6). Therefore, the estimated mean selection length corresponding to the smaller $(2.4 \mathrm{~cm}$ mesh bar) net was $12.4 \mathrm{~cm}$ and that estimated for the larger meshed trammel net (2.8 cm mesh bar) was $14.4 \mathrm{~cm}$. 


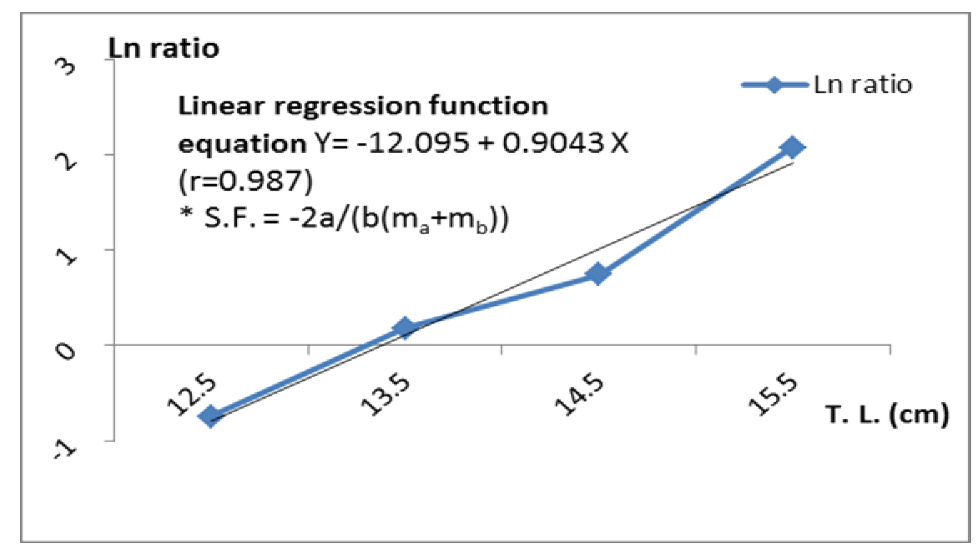

Note: * S.F. $=$ selection factor, "a" and "b" = constants of regression equation and $\mathrm{m}_{\mathrm{a}} \& \mathrm{~m}_{\mathrm{b}}=$ mesh bars of smaller and larger nets respectively

Fig. 6: Straight line showing Ln ratio of the two compared trammel nets.

Hence, the corresponding calculated weight was $37 \mathrm{gm}$ for the former and $58 \mathrm{gm}$ for the second mean selection length.

\section{DISCUSSION}

The present data indicated that tilapia species are the most common in the commercial catch of Rosetta branch of the River Nile. The landed catch was dominated by $O$. niloticus. Similar results were recorded by Hatem and Mazrouh (2008).

Both of the total catch and tilapia catch showed a decreasing trend $\left(r^{2}=0.65 \&\right.$ 0.38 respectively). This decrease may be due to many factors as a higher exploitation rate or began to be under an overexploited case as revealed by Hatem and Mazrouh (2008) as well as using illegal fishing gears in the river and selective fishing which affected the parental stock of $O$. niloticus. A variety of factors are implicated including over- fishing with a continuing increase of fishing effort units which contributes to fisheries decline.

Lengths at first capture, as estimated from the probability of capture, $\left(\mathrm{L}_{\mathrm{c}}\right)$ at which $50 \%$ of the fish become vulnerable to capture were estimated to be $11.89 \mathrm{~cm}$ for the smaller meshed net $(2.4 \mathrm{~cm}$ mesh bar) and $12.22 \mathrm{~cm}$ for the larger one $(2.8 \mathrm{~cm})$. This difference reflects the differences of the mesh size of the inner layer of trammel nets (Table 2 \& Fig. 4 a,b) as the selectivity pattern of the trammel net depends on the mesh size of the inner net (Purbayanto et al., 2000).

Previous studies revealed that $O$. niloticus attained lengths $11.7 \mathrm{~cm}$ and $11.44 \mathrm{~cm}$ at the end of first year of life at Lake Mariut (Abaza, 2004) and Rosetta branch (Hatem and Mazrouh, 2008) in respective order. This interprets the lowest put in weight at such lengths because the maximum annual increments in weight were observed at the end of the third year of life for O. niloticus (Hatem and Mazrouh, 2008).

The estimated mean selection length corresponding to trammel net of $2.4 \mathrm{~cm}$ mesh bar was $12.4 \mathrm{~cm}$, while that corresponding to trammel net of $2.8 \mathrm{~cm}$ mesh bar was 14.4 $\mathrm{cm}$. Similar results were recorded by Al-Sayes (1976) who found that the mean selection lengths of $O$. niloticus were $11.34 \mathrm{~cm}$ for trammel net of $4.28 \mathrm{~cm}$ (stretched mesh or $2.14 \mathrm{~cm}$ mesh bar) and $14.63 \mathrm{~cm}$ corresponding to that of $5.52 \mathrm{~cm}$ stretched mesh size (or $2.76 \mathrm{~cm}$ mesh bar) at Lake Borollus. Also, El-Bokhty (2004) found that the mean selection length was $11.43 \mathrm{~cm}$ corresponding a trammel net of $2.47 \mathrm{~cm}$ and $13.24 \mathrm{~cm}$ corresponding to $2.86 \mathrm{~cm}$ mesh bar for the inner layer of nets used at Lake Manzalah. These individual variations may return to the morphological variations of $O$. niloticus in different habitats beside the variations in the mesh sizes in different nets. 
El-Zarka (1970) reported that tilapia fish in lake Mariut are caught at average length $11 \mathrm{~cm}$. This size don't affect the breeding success of the fish because tilapia are known as fractional spawners and reach its first maturity and spawns at this size and even at smaller lengths. Also, Hosny et al. (1990) declared that the optimum size at first capture corresponding to the optimal yield in weight per each recruit for the four tilapia species in lake Manzalah (under the actual fishing and natural mortality rates) would be about $2^{+}$year which corresponds to a minimum size limit of $12 \mathrm{~cm}$ that would permit one whole season for the spawning process. This would not only prevent recruitment over fishing but will increase the total yield of the lake under the actual levels of the fishing effort.

According to the equation $\mathrm{W}=0.023966 \mathrm{~L}^{2.92209}$, the total weight of $O$. niloticus will be $36 \mathrm{gm}$ at length $12.2 \mathrm{~cm}$ corresponding to the larger trammel net. Raising $\mathrm{L}_{\mathrm{c}}$ values to $15 \mathrm{~cm}$ as a target optimum length will make a shift in weight reaching $65 \mathrm{gm}$. Hence, this could increase the catch weight and improve the quality of the species caught by such gear based on the criterion of gaining extra-weight and could lead to more economic returns. Thus, it is highly recommended to use trammel of mesh sizes for its inner layer not less than $60 \mathrm{~mm}$ stretched or $30 \mathrm{~mm}$ mesh bar to achieve this goal.

The elastic increase in the overall fishing effort resulted in reducing the CPUE in combination with reduction of mesh sizes in the used gears have led to the over-fishing problem (Hatem and Mazrouh, 2008) and decline of the fish catch of the River Nile in general beside on environmental factors which should be considered.

Fisheries management have hitherto targeted size regulation of mesh sizes of fishing gears which is preferable since it doesn't have drastic effects on fishermen as restricting the fishing effort (Gulland, 1978). These are difficult to be controlled in such water bodies without enforcing laws.

\section{CONCLUSION}

For fishery management of $O$. niloticus fishery in Rosetta branch, the fishing pressure and the use of smaller mesh sizes especially of trammel nets used need to be changed by the authorities concerned based on the criterion of gaining extra weight and raised to met with an inner layer of $3 \mathrm{~cm}$ mesh bar to catch lengths of $15 \mathrm{~cm}$ as an optimum length which will lead to an increase in weight reaching $65 \mathrm{gm}$ and allowing the production of Nile tilapia.

\section{REFERENCES}

Abassy M.S., Ibrahim, H.Z. and El-Amayem M.M. (1999). Occurrence of pesticides and polychlorinated biphenyles in water of the River Nile at the estuaries of Rosetta and Damietta branches, north of Delta, Egypt. J. Environ. Sci. Health B., 34(2):255-267.

Abaza, K.M. (2004). Fish production from Lake Mariut in relation to its biogeochemical conditions. Ph. D. Thesis, Fac. Sci. Alex. Univ.

Abd-Alla, A. and K. M. Talaat (2000). Growth and dynamics of tilapias in Edku Lake, Egypt. Bull. Instit. Oceanogr. \& Fisher., A.R.E., 26: 183 - 196.

Abd-Allah, A.M.; El-Gindy A.A. and Debes E.A. (2006). Sea level changes at Rosetta promontory, Egypt. Egypt. J. Aqua. Res., 32 (1): 34 - 47.

Abd El-Azim, M.E. (1974). Biological studies on Tilapia nilotica and T. galilaea in Lake Nasser. M. Sc. Thesis, Fac. Sci., Alex. University.

Abd El-Aziz, E.H.; Ezzat, A.A. and El-Bassir, M.A. (1990). Growth assessment of Cichlid fish (Oreochromis niloticus, L.) from the Egyptian and Sudanese inland waters. Proc. Int. Symp. Biol. and Cul. Tilapias, Alex., 255 - 291. 
Abd El-Baky, T. E. and El-Serafy, S. S. (1990). Length weight relationship and relative condition factor of three species of cichlid fishes inhabiting Lake Manzalah, Egypt. Egypt. J. Aqua. Res., 16(1): 147 - 169.

Abd El-Satar, A.M. and Elewa, A.A. (2001). Water quality and environmental assessments of the River Nile at Rosetta Branch. Proceeding of the 2nd International Conference and Exhibition for Life and Environment, 3-5 April, 2001, Alexandria, Egypt. pp. 136-164.

Abdo, M.H. (2002). Environmental studies on Rosetta branch and some chemical applications at the area extend from El-Kanater El-Khyria to Kafr El-Zayat city. Ph.D. Thesis, Facu. Sci., Ain Shams Univ., Egypt.

Adam, E.A. (2004). Stock assessment of some important commercial fish species of Lake Nasser, Egypt. Ph.D. Thesis, Fac. Sci., Assiut. Univ., Egypt.

Akel, S.K. (1989). Effect of water pollution on Tilapia population in Lake Mariut. M.Sc. Thesis Fac. Sci., Alex., Univ. 211p.

Al-Sayes, A. A. (1976). Studies on experimental fishing twines and nets and their efficiency and selectivity in fishing operations in Lake Borrollus. Ph.D. Thesis, Fac. Sci., Alex. Univ., 292 pp.

Bakhoum, S.A. (1994). Comparative study on length-weight relationship and condition factor of genus Oreochromis in polluted and non-polluted parts of Lake Mariut, Egypt. Egypt. J. Aqua. Res., 20(1): 201 - 210.

Bakhoum, S.A. (1995). The food and feeding ecology of Oreochromis niloticus (Linn) and Oreochromis aureus (Steind.) in Lake Mariut, Egypt. Alex. Sci. Exch., 16(1): $71-85$.

Bakhoum, S.A. (2002). Comparative reproductive biology of the Nile Tilapia Oreochromis niloticus (L.), Blue Tilapia, Oreochromis aureus (Steind.) and their hybrids in Lake Edku, Egypt. J. Aquat. Biol. and Fish, 6(3): 121 - 142.

Bakry, M.F. (1996). Water quality condition on Damietta and Rosetta branches. Res. Inst. Channel Maintenance, Nat. Wat. Centre J. (20): 146 - 150.

Bayoumi, A.R. and Khalil, M.T. (1988). Tilapia fisheries in lake Manzalah, Egypt. Egypt. J. Aqua. Res., 14 (3): 87 - 99.

Donia, N.; El-Azizy, I. and Khalifa, A. (2003). Industrial pollution control of Rosetta branch, River Nile, Egypt. $7^{\text {th }}$ Int. Wat. Tech. Conf.: 235.

El-Bokhty, E. E. B. (2004). Biological and economical studies on some fishing methods used in Lake Manzalah. Ph. D.Thesis, Fac. Sci., TantaUniv. 264 p.

El-Haweet, A.A. (1991). Biological studies of some cichlid species in Lake Borollus. M.Sc. Thesis. Fac. Sci., Alex. University.

El-Sayed, A.M. (2006). Tilapia culture. CABI Public., Wallingford, Oxford shire, OX10 8DE, Uk.

El-Sayed, H.K. and Moharram, S.G. (2007). Reproductive biology of Tilapia zillii (GERV, 1848) from Abu Qir Bay, Egypt. Egypt. J. Aquat. Res., 33 (1): 379-394.

El-Shazly, A.A. (1993). Biological studies on four Cichlid fishes (T. nilotica, T. galilae, T. zillii, T. aurea) in Lake Maruit. M.Sc. Thesis, Fac. Sci., Zagazig University.

El-Zarka, S., Shaheen, A.H. and Aleem, A.A. (1970.) Tilapia fisheries in Lake Mariut. Age and growth of Tilapia nilotica (L.) in the Lake. Bulletin Institute Oceanography \& Fisheries, Egypt, 1:149 - 182.

Emmanuel, B.E.; Chukwu, L.O. and Azeez, L.O. (2008). Cast net design characteristics, catch composition and selectivity in tropical open lagoon. Afr. J. Biotech., 7(12): 2081-2089.

Eskander, A. (2004). Biological studies on the main Cichlid fishes of the Nozha Hydrodrome, Alexandria, Egypt. Ph.D. Thesis, Fac. Sci., Zagazig Univ., Egypt.

Essa, M.A. and Faltas, S.N. (1997). Impact of pollution problems on some fishery aspects of Tilapia in Lake Mariut basins, Egypt. Proceedings the $7^{\text {th }}$ Internat. Conf. 
on Environ. Protect. Is a must, Alex., Egypt. 419 - 441.

GAFRD (2002-2009). The General Authority of Fish Resources Development, Year Book of Fishery Statistics, Cairo, Egypt.

Gulland, J.A. (1978). Appraisal of a fishery. Methods for assessment of fish production in fresh waters. T. Bagenal (Ed.), IBP Handbook, No. 3, $3^{\text {rd }}$ Ed., Blackwell, Oxford, pp. $236-245$.

Holt, S. J. (1957). A method of determining gear selectivity and its application. Paper No. 515 Sci. meeting ICNAF/ICES/FAO. Lisbon.

Hosny, C. F. H.; Ezzat, A. A. and Dowidar, N. M. (1990). The over fishing problem of tilapias in Lake Manzala. Proceeding of International Symposium On Biology And Culture of Tilapias. 27-31 Oct., Alex., Egypt. pp. 190-210.

Huse, I. ; Lokkeborg, S. and Soldal, A.V. (2000). Relative selectivity in trawl, longline and gillnet fisheries for cod and haddock. ICES J. Mar. Sci., 57: 1271-1282.

Ishak, M.M.; Al-Sayes, A.A. and Talaat, K.M. (1985). Tilapia fisheries in Lake Borollus, Egypt. Kuwait Bull. Sci. Res., (6): 225 - 242.

Khalifa, U. S. A., Agaypi, M. Z. and dam, H. A.A. (2000). Population dynamics of Oreochromis niloticus L. and Sarotherodon galilaeus Art. 90-97. In: Sustainable Fish Production in Lake Nasser: Ecological Basis and Management Policy. J. F. Craig (ed.) ICLARM Con. Proc., 61:184 p.

Khallaf, E. A. (2002). An ecological assessment of Bahr Shebeen Nilotic Canal (A Review Paper, presented at the $9^{\text {th }}$ International Conference, 1-6 September, 2002, Aleppo University, Syria). J. Union Arab Biol., 17: 65-75.

Khallaf, E. A. Galal, M. and Authman, M. (2000). The biology of Oreochromis niloticus in a polluted canal. In the International Congress on the Biology of Fish. 20-23 July 2000, University of Aberdeen, Scotland, UK. Pp: 17.

Le Cren, E.D. (1951). The length weight relationship and seasonal cycle in gonad weight and condition in Prech Perca fluviatilis. J. Am. Ecol., 20, (2): 201 - 219.

Mahmoud, H. Hatem and Mazrouh, M. Marwa (2008). Biology and Fisheries management of tilapia species in rosetta branch of the River Nile, Egypt. Egyptian J. Aquatic research, vol., 34: special Issue, 2008.

Marwa M. Mazrouh and Hatem H. Mahmoud (2009). Some Aspects of Reproductive Biology with Emphasis on the Effect of Pollution on the Histopathological Structure of Gonads in Oreochromis niloticus from Rosetta Branch, River Nile , Egypt. World Journal of Fish and Marine Sciences 1 (3): 190-198, 2009

Massoud, S.A.H. and Mahdi, H.A. (1985-a). Liminological investigation of Rosetta branch of the River Nile (Egypt). I. Environmental conditions. Fresh Water Biology 15 (6): $645-653$.

Massoud, S.A.H. and Mahdi, H.A. (1985-b). Liminological investigation of Rosetta branch of the River Nile (Egypt). II- Seasonal variation of nutrients. Fresh Water Biology 15 (6): $655-660$.

Mehanna, S.F. (2005). Population dynamics and management of the Nile tilapia Oreochromis niloticus in Wadi El-Raiyan Lakes, Egypt. African J. Biol. Sci., 1 (1): $79-88$.

Millar RB, Holst R, (1997). Estimation of gillnet and hook selectivity using log-linear models. ICES J. Mar. Sci. 54: 471-474.

Purbayanto, A. Akiayama, S. Tokai, T. and Arimoto, T. (2000). Mesh selectivity of a sweeping trammel net for Japanese whiting Sillago japonica. Fish. Sci., 66:79-103.

Talaat, K.M. (1979). Application of some growth models on Tilapia population in Lake Nasser and some other area of Egyptian inland water. M.Sc. Thesis, Fac. Sci., Alex. Univ. 
Welcomme, R. L.; Ian, G. Cowx; David Coates; Christophe Béné; Simon Funge-Smith; Ashley Halls and Kai Lorenzen (2010). Inland capture fisheries. Philos Trans R Soc Lond B Biol Sci. 2010 September 27; 365(1554): 2881-2896.

\section{ARABIC SUMMARY}

$$
\begin{aligned}
& \text { بعض جوانب مصايد البلطى النيلى بفرع رشيد - نهر النيل - مصر } \\
& \text { العزب العزب بدر البختى و علاء محمود الفار }
\end{aligned}
$$

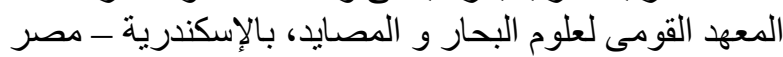

تم دراسة اسماك البلطى السائدة فى نهر النيل - فرع رقام رشيد الناتجه من الصيد التجارى لشباك الدابه ثلاثية

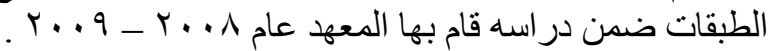

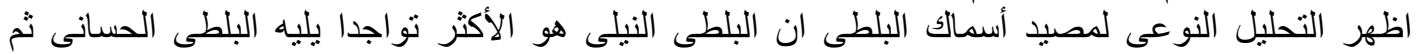

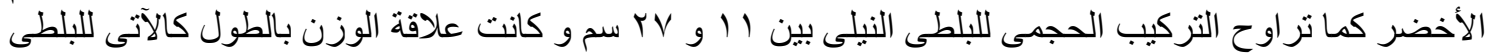

$$
\mathrm{W}=0.023966 \mathrm{~L}^{2.92209}
$$

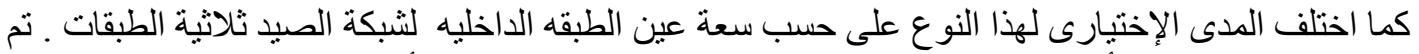

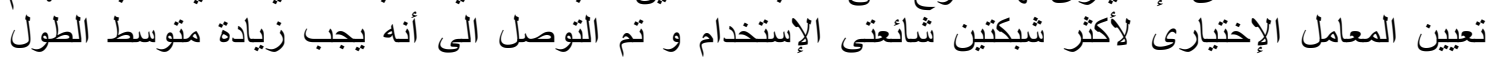

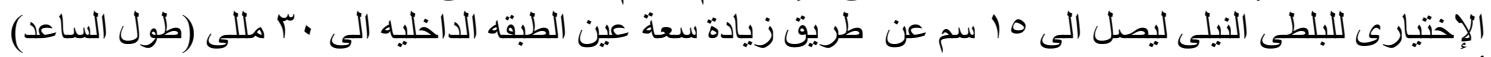

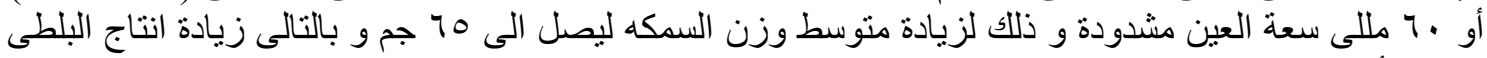

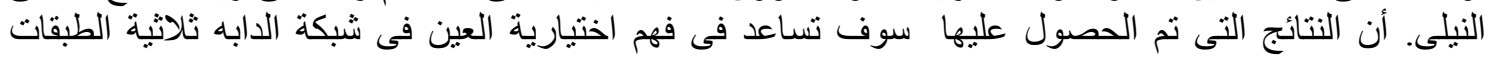
المستخدمه و فى ادارة مصايد البلطى النيلى بنهر النيل . 